\title{
Some Remarks on Historical
}

\section{Archaeology in Sweden between 1986 and 1990}

\section{Based on "Nordic Archaeological Abstracts"}

\section{Lars Redin}

\begin{abstract}
This study of Medieval Archaeology presents a quantitative survey of publications as they appear in NAA 1986 to 1990. The survey indicates a shift of interest in those years from urban archaeology to other areas, i. e. castles, iron production and in some sense rural activities. A significant growth of interest in theory and methods can be detected which could be considered as a sign of maturity of Medieval Archaeology in Sweden.

The status of Medieval Archaeology in the research society is discussed and is considered to be quite low. It is suggested that the reason for this is the fact that the subject has a rather vague identity.
\end{abstract}

Lars Redin, The Museum of National Antiquities, Box 5405, S-114 84 Stockholm, Sweden.

Some initial considerations should be presented. "Historical archaeology" is to be understood as archaeology applied to the period from the early Middle Ages up to present time. The Middle Ages start about the year $1000 \mathrm{AD}$ or $150-200$ years later, depending on where in Sweden you are - in the south, in the middle or in the north.

In this paper the term "Sweden" means Sweden of today, not Sweden of the Middle Ages which would exclude the former Danish and Norwegian provinces and include Finland; it does not mean Sweden of the 17th century either, which would cover the major parts of the coasts of the Baltic. We are, after all, evaluating a contemporary phenomenon the archaeology of our time - not the history of the past. Still, there seems to be some sense in making this statement; otherwise misunderstanding could occur. An evaluation of Swedish medieval research was car- ried out by a prominent group of Swedish scholars in the year 1987 (Dahbäck G. ed. 1987). In that study "Swedish" meant Swedish of the Middle Ages, indicating those parts of medieval Sweden which are still Swedish, not the Finnish ones for instance. We are more unsophisticated in this study, not daring to mix the present and the past in this subtle way and we will stick to one dimension: this is a study of how archaeology in Sweden is dealing with the historical past as reflected in Nordic Archaeological Abstracts.

We will be looking at five years of published research. Five years can be considered a short period or a long one in the development of research history. Swedish archaeology has been involved in the study of the historical period for a considerable time now, more than a century in fact. Seen in this perspective, five years in the 1980 s 
would be of small significance. The author will claim differently and in doing so argues from a narrower perspective. (In fact the author introduces an ambiguous phenomenon into this study. On the one hand, he is talking about archaeologists in a general sense; any archaeologist who has been researching the Middle Ages. On the other hand, he is interested in the academic discipline of medieval archaeology and in specialized medieval archaeologists. One can say that he is mainly interested in two things: 1 . Archaeological research in the period from the beginning of the Middle Ages onwards. 2. The development and status of medieval/ historical archaeology.)

Medieval archaeology has been taught from the early $1960 \mathrm{~s}$ in Lund, and has resulted in six academic licentiate degrees in the last part of this decade. The first doctoral degree in medieval archaeology was bestowed in 1976. By the end of 199316 doctoral theses in medieval archaeology had been presented in Lund. In addition, several doctoral theses dealing with the Middle Ages have appeared at other institutes of archaeology in Sweden. This should clearly demonstrate that the last 25 years have seen a considerable development of historical archaeology from a scholarly point of view.

Furthermore, until about 1975 medieval archaeology was a concern primarily for the south and southwest of Sweden, in the first hand for the province of Skanne. In the $1970 \mathrm{~s}$ large scale excavations were started in other parts of the country with a preference to historical urban centres in the middle of Sweden. This meant, in the first hand an enormous quantitative expansion of medieval archaeology and eventually also a qualitative development; one aspect, which should not be underestimated, is the fact that other perspectives than the southscandinavian ones became more obvious. Today historical archaeology in Sweden covers the whole country, from the very south to the Polar Circle in the north, from the most easterly archipelago in the Baltic to the peripheral mountains at the Norwegian border in the west.

To this sketchy background, can be added that medieval archaeology has established itself in the archaeological family in a more pronounced sense than before - methodologically, theoretically and also with respect to identity. The identity of the subject was until rather late quite vague - a mixture of art history, history, ethnology and archaeology. True, these elements should be present in a historical archaeology worth the name, but they should not create an identity problem, which they did. This problem of identity is demonstrated by the fact that the true characteristics of the subject are discussed with some regularity. See for instance META 1988 1-2 (Cinthio, Andrén, Wienberg, Österberg, Andersson). This does not seem to be an issue today. Historical archaeology is a grown-up member of the archaeological family, in some fields a leading member.

Our five years of medieval archaeology saw a shift of generation, most significantly demonstrated by the fact that the first professor of medieval archaeology in Lund, Eric Cinthio, was succeeded by the second one, Hans Andersson, in 1987. By and by this meant the formation of a group of young students who were not directly influenced by Cinthio's vision of the subject, in which elements from archaeology, art history, history and philosophy mingled into a synthesis with many facets. The effects of this shift will not appear in our five years of publications; it will take about five years from the formation period for them to make a forceful appearance in the outside world. It will be the task of the evaluator of the years 1991-95 to consider the effects of this change.

Anyhow, this is a background which permits us to claim that five years in the 1980s have some significance when it comes to evaluating the status and general trend of medieval/historical archaeology. 
Still, even if we accept the significance of the 1980s for the development of medieval archaelogy in Sweden we can question the maturity of the subject at that time in view of some obvious facts. We alluded earlier to the publication Svensk medeltidsforskning i dag (Medieval Research in Sweden Today; Dahlbäck, ed. 1987). None of the five contributors to that survey was a medieval archaeologist or an archaeologist in any other respect. In the publication medieval archaeology is included - after all, the subject is the only academic one in Sweden entirely devoted to the Middle Ages. Archaeological research in the period is analysed and evaluated and a future strategy is suggested by an art historian and a historian, respectively. Obviously at that time medieval archaeologists were not highly valued from a scholarly point of view. This estimation can be backed up by datas from NAA 1986-90, which will be demonstrated further on in this paper.

\section{EXPECTATIONS AND WISHES -}

\section{A PERSONAL INTERLUDE}

When preparing this paper I had some expectations as to how Swedish medieval archaeology would appear. Some of these expectations can be summarized as follows:

- a shift of focus from urban archaeology to agrarian archaeology

- an orientation toward problems in the economic sphere, like modes of production and changes in the technology of production

- that the urban archaelogy would be less dominated by purely topographical aspects compared with the previous period

- a substantial increase in publications on the themes Saami and Iron production

- a vigorous activity within osteological research and a corresponding increase in publications as a response to the fact that in the previous period about 120 cemetaries were touched by archaeological excavations and about 7000 medieval skele- tons were documented (Redin 1991)

- that the interpretations of the medieval society would be more complex and based on theoretical perspectives and would use more sophisticated archaeological methods.

I had wished - partly against my better knowledge - that:

the fact that medieval archaeologists in the previous ten years probably had outnumbered archaeologists of any other prehistoric period, would have an influence on the general archaeological debate - church archaeology would finally be established, and that we would not have to face the embarressing situation that investigations and documentations of medieval churches were neglected or carried out by, from many aspects, ignorant art historians or architects (judging from the present situation, this wish was a real utopian one)

- we would more frequently meet a medieval archaeology that would dare to accept the value of archaeological sources and data alongside sources and data of other kinds (historical, scientific, geographic, etc) and be prepared to establish independent interpretations

- we would see a new interest among the archaeologists in using the possibilities offered by the archaeological artefacts in the research. Swedish archaeology has in fact neglected this important source material on the medieval society

- the medieval archaeological experience would be sought and valued by other disciplines as an important contribution to the general understanding of historical processes.

A proper evaluation of these expectations and wishes would necesitate a study of similar kind from the time period 1976-1985. Not that the reader must accept my proposal at face value; the above points are subjective 
and as such more adapted to discussions than research. Discussions can be of value! So....

\section{NAA 1986-90 - WHAT CAN BE UNDERSTOOD ABOUT MEDIEVAL ARCHAEOLOGY?}

When writing this I have at hand four printed volumes of NAA namely those from the years 1986-1989. In these there were 1395 Swedish abstract titles on the prehistoric period and 1028 on medieval and postmedieval time. Consequently the later period has been covered with about $42.4 \%$ of all the abstracts systematized in a periodical perspective. This does not give a fair estimation, however. The premedieval abstracts should on the whole be seen as the products of archaeologists, but the medieval and the postmedieval ones are to a substantial part written by specialists within other academic disciplines, like art history, linguistics, history and human geography. Of all publications covered by abstracts in NAA in the years 1986-89 dealing with the Middle Ages and postmedieval time, about $9 \%$ is written by Swedish archaeologists or by Swedish scholars of a clear archaeological orientation. If we also include the year of 1990 , which is at hand in the form of a manuscript (published in the autumn of 1994) it is in plain numbers a matter of 325 abstracts, on the whole about a fair share.

These 325 abstracts represent a variety of publications, from proper monographs, some of them doctoral theses, to short notices introducing some observation or object. Seminar papers are not included, although they can be of great interest as an indication of existing trends at the university institutes and in some cases are of high quality by any standard.

Figure 1 is a diagramatic presentation of these 325 abstracts grouped according to theme.

Of course a subdivision like the one demonstrated in this diagram can be questioned from many aspects. Any scholarly presentation worth the name should be relevant from a methodological and/or theoretical point of view, for instance. Much of the interest in iron research is directed towards the aspects of production, which makes the differentiation between Iron and Production dubious in some cases. Still, since research on iron and iron production is one of the most innovating and interesting developments in Swedish archaeology of today, this differentiation can be defended.

Let us accept the assumption that the diagram does give us some straight statistical information on the direction of medieval archaeological publications in Sweden between the years 1986 and 1990. Does it also give us an understanding of medieval/historical archeology and its status in the same years? Probably not. As pointed out earlier publications tend to represent thoughts and ambitions some years old when they are printed.

If we want to draw some conclusions from diagram 1 they are that urban archaeology is losing ground (from eighteen titles in 1986 to seven in 1990) and the interest in castles seems to be rising and the likewise in theory and methods. The year 1986 was apparently a good year for artefact studies. In the five years concerned, the themes Castles, Countryside, Underwater Archaeology and Numismatics also inspired a respectable amount of publishing acitivity (more than twenty titles in all). There is no indication, though, that the decrease in town archaeology correponded to an expansion of countryside archaeology (see expectation no 1). Six themes have produced between nine and sixteen titles and four only a few each. Church archaeology was well established and remained so during the five years. There was some acitivity in postmedieval archaeology, most on Underwater and Iron.

It can be worthwhile to look more closely at some of the themes. 


\begin{tabular}{|c|c|c|c|c|c|c|}
\hline Themes & NAA 1986 & NAA 1987 & NAA 1988 & NAA 1989 & NAA 1990 & Total \\
\hline Monastery & $x \times x(3)$ & $\operatorname{xxx}(3)$ & $-(0)$ & $x \times(2)$ & $x \times x x(4)$ & 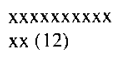 \\
\hline Town & $\begin{array}{l}x x x x x x x x x x \\
x \times x x x / 000 \\
(18 \quad 15 / 3)\end{array}$ & $\begin{array}{l}x x x x x x x x x x \\
x x(12)\end{array}$ & $\begin{array}{l}x x x x x x \times x \\
(8)\end{array}$ & $\begin{array}{l}x x x x x x x x x x \\
x / 0 \\
(1211 / 1)\end{array}$ & $\begin{array}{l}x x x x x x x \\
(7)\end{array}$ & $\begin{array}{l}x x \times x x x x x x x \\
x x \times x x x x x x \\
x x x x x x x x x x \\
x x x x x x x x x x \\
x x x x x x x x x x \\
x x x / 0000 \\
(5753 / 4)\end{array}$ \\
\hline Church & $\begin{array}{l}x x x x x x x x x x \\
x x(12)\end{array}$ & $\begin{array}{l}x x x x x x x x \\
(8)\end{array}$ & $\begin{array}{l}x x x x x x x x \\
(8)\end{array}$ & $\begin{array}{l}x x \times x \times x x / 0 \\
(87 / 1)\end{array}$ & $\begin{array}{l}x x x x x x x x x x \\
x x(12)\end{array}$ & 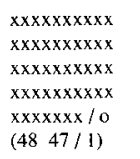 \\
\hline Castles & $\begin{array}{l}x x x x / 00 \\
(64 / 2)\end{array}$ & $x \times(2)$ & $x x x \times x(5)$ & $\begin{array}{l}x x x x x x x / 0 \\
(87 / 1)\end{array}$ & $\begin{array}{l}x \times x x x x x / 0 \\
(87 / 1)\end{array}$ & $\begin{array}{l}x x x x x x x x x \\
\text { xxxxxxxxxx } \\
\text { xxxxx/0000 } \\
(2925 / 4)\end{array}$ \\
\hline Countryside & $\operatorname{xxxxxxx}(7)$ & $\begin{array}{l}x x x x x / 0 \\
(65 / 1)\end{array}$ & $x x(2)$ & $\operatorname{xxxxx}(5)$ & $x x x x(4)$ & 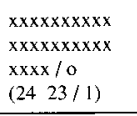 \\
\hline Artefacts & $\begin{array}{l}x x x x x x x x x x \\
x x / 00 \\
(1412 / 2)\end{array}$ & $x x x(3)$ & $x \times x(3)$ & $x x x x(4)$ & $x x(2)$ & $\begin{array}{l}x x x x x x x x x x \\
x x x x x x x x x x \\
x x x x / 00 \\
(26 \quad 24 / 2)\end{array}$ \\
\hline $\begin{array}{l}\text { Theory/ } \\
\text { Methods }\end{array}$ & $x(1)$ & $x x(2)$ & $x x x x(4)$ & $\mathrm{xxx}(3)$ & $x \times x x(4)$ & 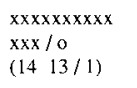 \\
\hline Underwater & $\begin{array}{l}x x x / 00000 \\
(83 / 5)\end{array}$ & $\begin{array}{l}x \times x / 00 \\
(53 / 2)\end{array}$ & $x(1)$ & $\begin{array}{l}x x x / 00 \\
(53 / 2)\end{array}$ & $\begin{array}{l}x x / o o \\
(42 / 2)\end{array}$ & 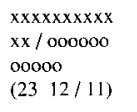 \\
\hline $\begin{array}{l}\text { Ancient } \\
\text { monuments }\end{array}$ & $x \times x(3)$ & $\begin{array}{l}x \times x / 0 \\
(43 / 1)\end{array}$ & $\mathrm{xx}(2)$ & $x(1)$ & $\begin{array}{l}x \times x \times x / 0 \\
(65 / 1)\end{array}$ & $\begin{array}{l}x x x x x x x x x x \\
x x x x / 00 \\
(1614 / 2)\end{array}$ \\
\hline Building & $\begin{array}{l}x \times x x x / 00 \\
(75 / 2)\end{array}$ & $x(1)$ & $\begin{array}{l}x \times x / 0 \\
(43 / 1)\end{array}$ & $x(1)$ & $x(1)$ & $\begin{array}{l}x x x x x x x x x x \\
x / 000 \\
(1411 / 3)\end{array}$ \\
\hline Numismatics & $x \times x x(4)$ & $\operatorname{xxxxxx}(6)$ & $-(0)$ & $x \operatorname{xxxxxxx}(8)$ & $x x x x(4)$ & $\begin{array}{l}x \times x x x x x x x x \\
x x x x x x x x x x \\
x \times(22)\end{array}$ \\
\hline Osteology & $\operatorname{xxx}(3)$ & $\operatorname{xxx}(3)$ & $-(0)$ & $x x / 0(32 / 1)$ & $x \times(2)$ & $\begin{array}{l}x x x x x x x x x x / \\
o\left(\begin{array}{lll}11 & 10 / 1\end{array}\right)\end{array}$ \\
\hline Production & $x \times x x x(5)$ & $x(1)$ & $x(1)$ & $x(1)$ & $x(1)$ & $\begin{array}{l}x x x x x x x x x \\
(9)\end{array}$ \\
\hline Iron & $\begin{array}{l}x x / 000 \\
(52 / 3)\end{array}$ & $-(0)$ & $/ 0(10 / 1)$ & $\begin{array}{l}x \times x / 00 \\
(53 / 2)\end{array}$ & $-(0)$ & $\begin{array}{l}x \times x x x / 0000 \\
00(115 / 6)\end{array}$ \\
\hline $\begin{array}{l}\text { Linguistics/ } \\
\text { Runes, Saami, } \\
\text { Technology, } \\
\text { Typography }\end{array}$ & $\mathrm{xx}(2)$ & $\begin{array}{l}x x x / 0 \\
(43 / 1)\end{array}$ & $x(1)$ & $\mathrm{xx}(2)$ & $x(1)$ & 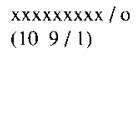 \\
\hline $\begin{array}{l}\text { Total } \\
\text { med / p.med }\end{array}$ & $\begin{array}{l}98 \\
81 / 17\end{array}$ & $\begin{array}{l}60 \\
55 / 5\end{array}$ & $\begin{array}{l}39 \\
35 / 4\end{array}$ & $\begin{array}{l}68 \\
60 / 8\end{array}$ & $\begin{array}{l}60 \\
55 / 5\end{array}$ & $\begin{array}{l}325 \\
285 / 40\end{array}$ \\
\hline
\end{tabular}

Fig. 1. Abstracts written by medieval archaeologists on medieval and postmedieval period grouped according to themes. $x /=$ medieval. $/ 0=$ postmedieval 


\section{CHURCH ARCHAEOLOGY}

Churches seem to have been a major concern for Swedish medieval archaeology (47 titles between 1986 and 1990). This quantitative description does not say much. The qualitative aspects must be treated too.

So what is the real direction of archaeological interest in churches? There are a lot of different approaches to the presentations (small church descriptions, technical aspects of vaulting, single notations of architectural details, etc.). About $20 \%$ represents rather simple descriptions of excavations in churches, most of them rather limited; there are a few larger excavations, though. St Hans in Visby was more or less completely excavated during this period in a reseach project which activated many aspects on the chronology of the Visby churches. The cathedral of Uppsala was also excavated and its walls were investigated archaeologically - and the results were published (Swanström 1986, Malm 1987). Church archaeologists have treated methodological problems such as using dendrochronology (Sundnér 1990, Wienberg 1989). There are a number of publications arguing for and using medieval churches as a source for studying social and economic aspects in the medieval society (Claesson 1989, Holmberg 1990, Redin 1988, Sundnér 1989). One of these is a dissertation for the licentiate degree, an other is a monograph on how elements in the medieval parochial churches in the south of Sweden relate to changes in society. In 1986 a "festschrift" in honour of Erik Cinthio, who was about to retire, was published with contributions by his former and present students (Andrén et al. (Ed.) 1986). Of the twentysix articles in this book, eight treated churches, which can be seen as an expression of the interest in church archaeology at the Institute of Medieval Archaeology in Lund.

One of the most ambitious studies of churhces appears in By, huvudgård och kyrka, a product of the Institute of Medieval
Archaeology in Lund and a part of a larger interdisciplinary project on an area in eastern Scania. A group of scholars investigated and analysed twentyone churches and conducted a discussion on building techniques and chronology, dendrochronology, the ecclesiastical organisation and demography. The study is quite interesting methodologically and theoretically, and it also demonstrates the value of churches as a general source material on changes in the society (Andersson \& Anglert (Ed.) 1989).

By, huvudgård och kyrka is based on the collecting and systematisation of available data. This might be seen as a significant characteristic of non documentary research on the Middle Ages for some time. It can be seen in earlier works like Andrén 1985, Liepe 1985, and not the least in the project Medeltidsstaden and its reports. This certainly expresses a need to establish surveys of phenomena often refered to but seldom properly accounted for. In 1987 Kyrkorna berättar by A-C. Bonnier was published, a dissertation not in medieval archaeology but in art history and containing a study of medieval churches in Uppland based on the systematization of available information (archaeological, art historical and documentary) (Bonnier 1987). In many respects this study shows close kinship with the archaeological studies mentioned and can consequently defend its place here in this paper. One difference, however, is that the archaeologists in most cases use the churches to investigate general processes in the society whereas for Bonnier the churches themselves are the object.

If we want to say something conclusive about the general direction of the above studies of churches, it is that they have the ambition to understand their objects in the light of social and economic changes in the medieval society. What is missing, however, is a dynamic excavation acttivity. The research activity which has been carried out is mainly based on data from existing docu- 
mentation. Only rarely are there presentations of newly excavated churches and normally they are small ones. It is clear that the number of churches investigated by archaeologists does not correspond at all to the number of churches which should have been investigated.

\section{TOWNS}

As noted earlier our five years represent a period of declining interest in urban archaeology. At least it seems so from a purely quantitaive point of view - the qualitative evaluation is a bit more complex. It is true that there is a tendency towards a dominance of more and more short notes and minor reports on archaeological acitivities in the later years of the period. One can also consider some efforts in the earlier years to be more ambitious like discussions on feudal urbanization (Klackenberg 1986). A monographic doctoral thesis on Skanör in 1988 (Ersgård 1988), can be seen as a conclusion to archaeological activities from the $1970 \mathrm{~s}$ and the early 1980s. It is an advanced study of the development of two towns in the southeasterly corner of Scania, where economic activities at the herring markets, royal power, and social structures have contributed to a development of a very special kind.

In retrospective, nothing like it has been published in Sweden since, which makes it easy to accept that urban archaeology has changed direction. New perspectives can be expected.

Such new perspectives might or might not appear from some new research projects which were started in the late 1980s, one of them on Kungahälla (Carlsson (Ed.) 1988). Today it is quite clear that a successful initiative was taken in 1987 to establish a new start for Sigtuna research, not least a new start for Sigtuna archaeology (Tesch (Ed.) 1988). This was an initiative to establish a cross disciplinary research climate, which will be of great value in the coming years.

In conclusion urban archaeology reached the end of the very dynamic period which started at about 1975 and which concerned itself mainly with topographical aspects of town development. Almost symbolically the latest of the reports in the series Medeltidsstaden appeared in the year 1990; in fact about a preurban location: Köpingsvik on Öland (Johnsson \& Schultze 1990). A new phase of archaeological reseach on towns must certainly be based on new ideas but at the same time on bringing new data into the picture. Whether these new ideas will be directed towards mental, cultural or material areas, I am quite convinced that archaeological artefacts will contribute some of the data in a much more developed way than has been the case in the past.

\section{COUNTRYSIDE}

I have claimed that diminishing urban archaeology has not led to an expansion of archaeology in the countryside. This does not mean that the urban experience has not inspired efforts outside the towns. A discussion started around 1980 about the concept of "omland" (hinterland, surroundings). The discussion inspired some efforts in the later years (e.g. Redin 1986), most notably a doctoral thesis on Blekinge, which studies the relationship between the human use of the landscape and the formation of central places from around 600 A.D to the middle of the seventeenth century (Stenholm 1987). The theses is rather descriptive, bringing together a lot of different aspects of this rather peripheral province of medieval Denmark along established methodological lines. A new approach to the relationship between town and "omland" is used in the short paper Urban and rural consumption patterns in eastern central Sweden A.D. 1000-1700, which demonstrates the great possibilities inherent in excavated artefacts and ecofacts. It clearly demonstrates the effects of towns on rural production and consumptions (Broberg \& Svensson 1987). One might have expected a treatment of the town - "omland" 
concept in By, huvudgard och kyrka since it is a study of a landscape around the town Ystad, but this study is directed towards the rural landscape as a separate unit (Andersson \& Anglert, (Ed.) 1989; see however Andersson et al 1991).

Anders Broberg has made a thorough analysis of a settlement in the countryside in the north of the province of Uppland and has presented it in his doctoral thesis (Broberg 1990). He follows the development from 700 A.D. to around 1350 from establishment to decline. Especially interesting is that he carries out an estimation of maximal production capacity and relates it to variations in habitation intensity and population growth.

One conclusion about the theme Countryside is that the number of abstracts is not very great, but they represent some of the most interesting and promising contributions to the development of medieval/historical archaeology. It might be that rural life was basic in the Middle Ages and dealing with it encourages the ambition to establish a synthesis. And after all this is the aspect of the preindustrial society, which is least known from other sources.

\section{ARTEFACTS}

Medieval archaeologists in Sweden are normally not inclined to devote themselves to artefact study, regrettably so as has been mentioned earlier in this paper. Some major efforts are represented in the publications between 1986 and 1990 though. In 1986 Anders Lindahl published his doctoral thesis, a technological study of glazed earthenware from Dalby in Scania. In doing so he convincingly established this specialized and scientific approach to medieval ceramics along lines which had been developed at the Department of Quaternary Geology and its laboratory for pottery analysis (Lindahl 1986). Another example of a technical approach is a study of knives from the Eketorp ringfort (Arrhenius 1989). Apart from these works, however, the technological aspect of artefact reseach is very rare. An ambitious counterpart along more humanistic lines is represented by Lars Andersson's study of pilgrim badges and pilgrimage, which is in fact a study of pilgrimage in Scandinavia primarily based on finds of pilgrim badges (Andersson 1989).

That is about all there is to say about artefact studies within medieval archaelogy, and it should be considered against the background that the ten years preceding our period saw an enormous expansion of find material from excavations in the medieval towns. Yet there is almost no trace of this fact in NAA 1986-90. Even more startling is the fact that the situation has not changed much since 1990.

The question is, are the medieval artefacts of no value as a source of the Middle Ages?

\section{THEORY, METHODS AND IDENTITY}

I claimed in the beginning of this study that medieval archaeology had established itself in the archaeological family methodologically and theoretically and with an identity of its own. This statement should be looked at more closely. It can be said that the contribution of Swedish medieval archaeologists to the theoretical development of archaeology as a whole is not very impressive. In the subject index of NAA only about $5.6 \%$ of all abstracts under the subjects Archaeology, Methods and Theory are written by medieval archaeologists. True, there is an indication that the interest in a more theoretical approach is increasing among the medieval archaeologists as can be seen from figure $\mathrm{nr} 2$.

When this was written NAA 1990 only existed in the form of a munuscript, which prevented including the values of that year.

Still, to some degree this is a demonstration of a domestic exchange of ideas: medieval archaeologists are discussing medieval archaeology with other medieval archaeo- 


\begin{tabular}{|c|c|c|c|}
\hline & Total numbers of abstracts & $\begin{array}{l}\text { Numbers of abstracts by } \\
\text { medieval archaeologists }\end{array}$ & $\begin{array}{l}\text { Percentage of abstracts by } \\
\text { medieval archaeologists }\end{array}$ \\
\hline NAA 1986 & 53 & 2 & $3,8 \%$ \\
NAA 1987 & 69 & 2 & $2,9 \%$ \\
NAA 1988 & 57 & 4 & $7,0 \%$ \\
NAA 1990 & 112 & 10 & $8,9 \%$ \\
\hline
\end{tabular}

Fig. 2. Contribution of Sw. medieval archaeology to subjects Archaeology, Methods and Theory.

logists (META 1988 1-2, META 1989/1 pp 1-29, Welinder 1989). There are however examples, and not so very few either, of contributions of more general interest to a wider group of academic disciplines (i.e. Andersson 1990, Andrén 1986, Ersgård 1988, Klackenberg 1986, Myrdal 1987, (true the latter is a scholar of economic history, but still with experience from using artefacts from the Middle Ages), META 1988/1-2, Sundnér 1990, Wienberg 1988, 1989).

\section{SOME OBSERVATIONS}

We can make more observations of the same kind; the obvious rebirth of interest in castles and fortresses; a new trend or a coincidence? (Two monographs appeared: Ödman 1988, Mogren \& Svensson 1988; the research projects on Styresholm, Ångermanland and on the wooden defence "Bulverket" on Gotland produced a whole series of papers e.g. Wallander 1989, Rönnby 1989. Finally a conference about castles and fortresses was held: Melander (Ed.) 1989). Underwater archaeology should be mentioned with its strong influence from non-professional participants as well as Iron and Iron production. All are special interests within historical archaeology and can be seen as innovative in one sense or another. I would like to stress another phenomenon though, namely the existence of the periodical META. It is quite obvious that META has been of great importance to the development of medieval/ historical archaeology in Sweden during the time period. With its combination of infor- mality and quality it established itself as a platform for discussion, debate and information. During the period META identified important topics for discussion and contributed a lot toward developing them. In META medieval archaeology had something that Swedish Archaeology should have had.

Swedish medieval archaeology was not programatic as it appears in the publications of 1986-90. There is no allegiance to ideologies or schools of thought, no programatic declarations in its appearance. Ten years earlier there was more of such. Wether that should be interpreted as a sign of maturity or less vitality is an open question.

In the end I will bring us back to the aspect of medieval archaeology's position in the academic world as a whole. Who is interested in its results and problems? Who wants to consider its suggestions and interpretations? The study Svensk medeltidsforskning idag appreciated the existence of medieval archaeology, though more so as a possibility for the future than as a reality today at least when it comes to the question of a real contribution to understanding medieval Sweden (see Göran Dahlbäck:Svensk medeltid $i$ historiskt perspektiv and also Mereth Lindgren: Svensk medeltid i konstvetenskapligt perspektiv in Dahlbäck (Ed.) 1987). Much can be said in favour of that estimation, especially if you accept the geographical limitation of the study. Would this be the case if dealing with problems in e.g. a more general context?

So it would seem! At a conference in 
1988 at the Krapperup castle in Scania on the Birth of the Middle Ages only two participants out of twentyone were Swedish medieval archaeologists and only one of the two held a lecture (Andrén (ed) 1989). This underlines the fact that Sweden until then had produced very few scholars of medieval archaeology of such high standard that they could be accepted as partners in a discussion of that kind. This should be kept in mind and forms a background to the general direction of the publications of the years 1986-90.

Earlier in this study I touched upon the fact that medieval archaeology seems to have a problem with indentity. In a comment to Medeltiden och arkeologin (Andrén et al (Ed.)1986) Stig Welinder identified this problem and suggested that medieval archaeology should stop being a cross disciplinary hybrid (my interpretation) and give its attention to building up its selfconfidence. The method would be to accept that medieval archaeology is a humanistic discipline which should study the interrelationship between man, objects and the physical and ecological environment (Welinder 1989).

\section{REFERENCES}

Andersson, G. 1990. Gaturenhållning och hushållsavlopp - modern service eller medeltida teknik? Om Visby medeltida stadsmiljö utifrån det arkeologiska materialet. Gotlandia irredenta. Festschrift für Gunnar Svahnström zu seinem 75 .

Andersson, H. \& Anglert, M. (ed) 1989. By, huvudgård och kyrka. Studier i Ystadsområdets medeltid. Lund Studies in Medieval Archaeology 5.

Andersson, H. et al. 1991. Ystad and the hinterland. The cultural landscape during 6000 years in southern Sweden. Ed. Berglund, B.E. 1991, chapt. 5.8. Ecological Bulletins 41.

Andersson, L. 1989. Pilgrimsmärken och vallfart. Medeltida pilgrimskultur $i$ Skandinavien. Lund Studies in Medieval Archaeology 7.
Eva Österberg seems to think along the same lines when she - more politely and subtly perhaps - looks for a medieval archaeology that is less preoccupied with questions like "when did towns and villages appear, vanish?" and focus more on how they functioned as social arenas when they existed. Österberg points out that history as a subject has lately shifted from studying materialistic aspects to cultural ones; this should be the modern trend (Österberg 1988: $60)$. We can deduce that she could not identify a similar modernization in medieval archaeology.

A more humanistic approach, an ethnological readiness to understand the mental and cultural motives behind events identified by archeology, is what other disciplines seem to expect from medieval archaeology. This expectation was obviously not met in the years 1986-90. Perhaps it will be in the next five years, and if so, will that solve the identity problem of medieval archaeology in Sweden?

English revised by Laura Wrang.

Andrén, A. 1986. I städernas undre värld. Medeltidens undre värld. Andrén et al. 1986.

- 1987. Avgränsning eller tillhörighet? - olika principer för social organisation. Nordisk TAG Rapport från den forste nordiske TAGkonference i Helsing $\phi r$, 15-17 november 1985. (ed). K. Kristiansen.

- 1989. (ed). Medeltidens födelse. Symposier på Krapperups borg.

Andrén, A. et al. (ed). 1986. Medeltiden och arkeologin. Festskrift till Erik Cinthio. Lund Studies in Medieval Archaeology 1.

Arrhenius, B. 1989. Knives from Eketorp. An evidence of the growing influence of the centralized production from Medieval town communities. Laborativ arkeologi 3.

Bonnier, A-C. 1987. Kyrkorna berättar. Upplands 
kyrkor 1250-1350. Upplands fornminnesförenings tidskrift 51 .

Broberg,A. 1990. Bönder och samhälle i statsbildningstid. En bebyggelsehistorisk studie av agrarsamhället $i$ Norra Roden 700-1350. Upplands fornminnesförenings tidskrift 52.

Broberg, A. \& Svensson, K. 1987. Urban and rural consumption patterns in eastern central Sweden a.D. 1000-1700. Theoretical Approaches to Artefacts, Settlement and Society. Studies in honour of Mats P. Malmer. (ed) Burenhult et al. BAR International Series 366 (ii).

Carlsson, K. 1988. (ed). Kungahälla. Arkeologi 1985-1987. Kulturhistorisk rapport 21. Länsstyrelsen i Göteborgs och Bohus län.

Claesson, E. 1989. Cuius ecclesiam fecit. Romanska kyrkor $i$ Västergötland. Lunds universitet. Institutionen för medeltidsarkeologi. Stencil.

Dahlbäck, G. 1987. (ed). Svensk medeltidsforskning idag. En forskningsöversikt. Humanistiska samhällsvetenskapliga forskningsrådet.

Ersgård, L. 1988. "Vår marknad i Skåne" - Bebyggelse, handel och urbanisering i Skanör och Falsterbo under medeltiden. Lund Studies in Medieval Archaeology 4.

Holmberg, R. 1990. Kyrkobyggnad, kult och samhälle. Landskyrkan $i$ Lunds forna ärkestift genom tiderna. Lunds studies in Medieval Archaeology 8.

Johnsson, M. \& Schultze, H. 1990. Köpingsvik. Medeltidsstaden 77, Riksantikvarieämbetet och Statens Historiska Museer. Rapport.

Klackenberg, H. 1986. Feodalism i Finnveden: biskop Henrik och Berga. Medeltiden och arkeologin. (ed). Andrén et al.

Lindahl, A. 1986. Information through Sherds. A case study of the early glazed earthenware from Dalby, Scania. Lund studies in Medieval Archaeology 3.

Malm, G. 1987. Recent excavations at Uppsala Cathedral, Sweden. World Archaeology 18/3.

META Medeltidsarkeologisk tidskrift. Medlemstidning för Medeltidsarkeologiska föreningen. Lund.

Melander, J. 1989. (ed). Den medeltida borgen. Aspekter på aktuell borgforskning. Stockholm, RAÄ.
Mogren, M. \& Svensson, K. 1988. Bondeplågarens borg. Om och kring undersökningen av fogdefästet Borganäs i Dalarna. Stockholm: Riksantikvarieämbetet /UV.

Myrdal, J. 1987. Föremålens formlära - en metoddiskussion. META 1987/4.

$N A A=$ Nordic Archaeological Abstracts 1986, 1987, 1988, 1989, 1990.

Redin, L. 1988. Kyrkor, socknar, samhällsbildning... Medeltid. Katalog för utställning på Läckö Slott. (ed). Vogel-Rödin.

- 1991. Människan i medeltid - och hennes kvarlevor i nutid. Gravfälsundersökningar och gravarkeologi. (ed). Lagerlöf,A. Forskning för kulturmiljövård 3. Riksantikvarieämbetet.

Rönnby, J. 1989. Bulverket - undervattensarkeologiska undersökningar. Gotländskt arkiv 61.

Stenholm, L. 1986. Ränderna går aldrig ur - en bebyggelsehistorisk studie av Blekinges dansktid. Lund Studies in Medieval Archaeology 2.

Sundnér B. 1989. Kyrkor - ett arkeologiskt källmaterial ovan mark. META $1989 / 2$.

- 1990. Hantering av dendrokronologiska undersökningar i byggnadskonstruktioner - ett förslag. META 1990/1-2.

Swanström, E. 1986. "Allhelgonakyrkan", S:t Per och S:t Hans i Visby. Kyrkoarkeologi i Norden 2. Hikuin 12.

- 1988. S:t Hans kyrkoruin i Visby, en kompletterande undersökning. Gotländskt arkiv 60.

Tesch, S. 1988. (ed). Avstamp - för en ny Sigtunaforskning. 18 forskare om Sigtuna. Heldagsseminarium kring Sigtuanforskning den 26 november 1987. Gröna Ladan, Sigtuna. Sigtuna museer.

Wallander, A. 1989. Styresholmsprojektet. Arkeologi i norr 2.

Welinder, S. 1989. Arkeologi om människor med bokstäver men utan tvål. META 1989/2.

Wienberg, J. 1988. Dendrokronologi og kildekritik - om dateringen av Stora Köpinge kirkes romanske ombygning. META 1988/1-2.

- 1989. Kaos i tiden. META 1989/3.

Ödman, A. 1988. Stockholms tre borgar. Frain vikingatida spärrfäste till medeltida kastellborg. Stockholmsmonografier 80.

Österberg, E. 1988. Trender i historisk forskning om äldre tid och kontaktytor mellan medeltidsarkeologi och historia. META 1988/I-2. 
